\title{
A NEW SPECIES OF LIMNEPHILIDAE FROM MAINE (TRICHOPTERA)
}

\author{
By Nathan Banks \\ Holliston, Mass.
}

\section{Hydatophylax victor sp. nov.}

In general appearance similar to Allegophylax subfasciatus. Body, legs, antennae, palpi mostly pale yellowish; fore wings with a large brown or yellowish brown area, mostly over the posterior part of wing, sometimes covering the basal two-thirds of the front part also. The apical third of the discal cell and of the cell behind it remains clear whitish hyaline; this is usually connected to a similar spot in the apical part of the thyridial cell. These clear areas are constant, although the amount of dark above, before, and behind them varies.

There is a curved brown mark, somewhat before outer half of apical area, over the second and third apical cells. Sometimes the area beyond it is also darkened a little; the tips of the outer veins are also dark.

The surface of the fore wing is closely roughened as in Allegophylax. The venation of fore wing is similar to that of Allegophylax, except that the discal cell reaches almost as far back as the thyridial cell. In the hind wing the discal cell is also very slender and reaches much further basally than in Allegophylax. In the anal cells of the fore wing, the separation from Allegophylax is very distinct; the third anal cell being extremely long and slender.

The head is scarcely as broad as in Allegophylax, but the vertex and ocelli about the same. The pronotum is extremely short, as in Allegophylax, each side with tubercles and stout bristles.

The legs are also similar to Allegophylax, the front and middle tibiae spined to base, and on outer side a few spines near base. The hind legs are long; the tibiae spined a little before middle; the last joint of hind tarsus has one or two spines below.

The male genitalia has a pair of slender processes from the lower base, with more slender tips, these (seen from side) reach above the top of the last dorsal segment; from the side one sees a short median projection.

Length of fore wing: 14 to $16 \mathrm{~mm}$. 
Types numbered 28499 in the Museum of Comparative Zoology. Several specimens taken at light at Round Mt., Maine, by the Maine Forest Service, 15, 16, 17 July.
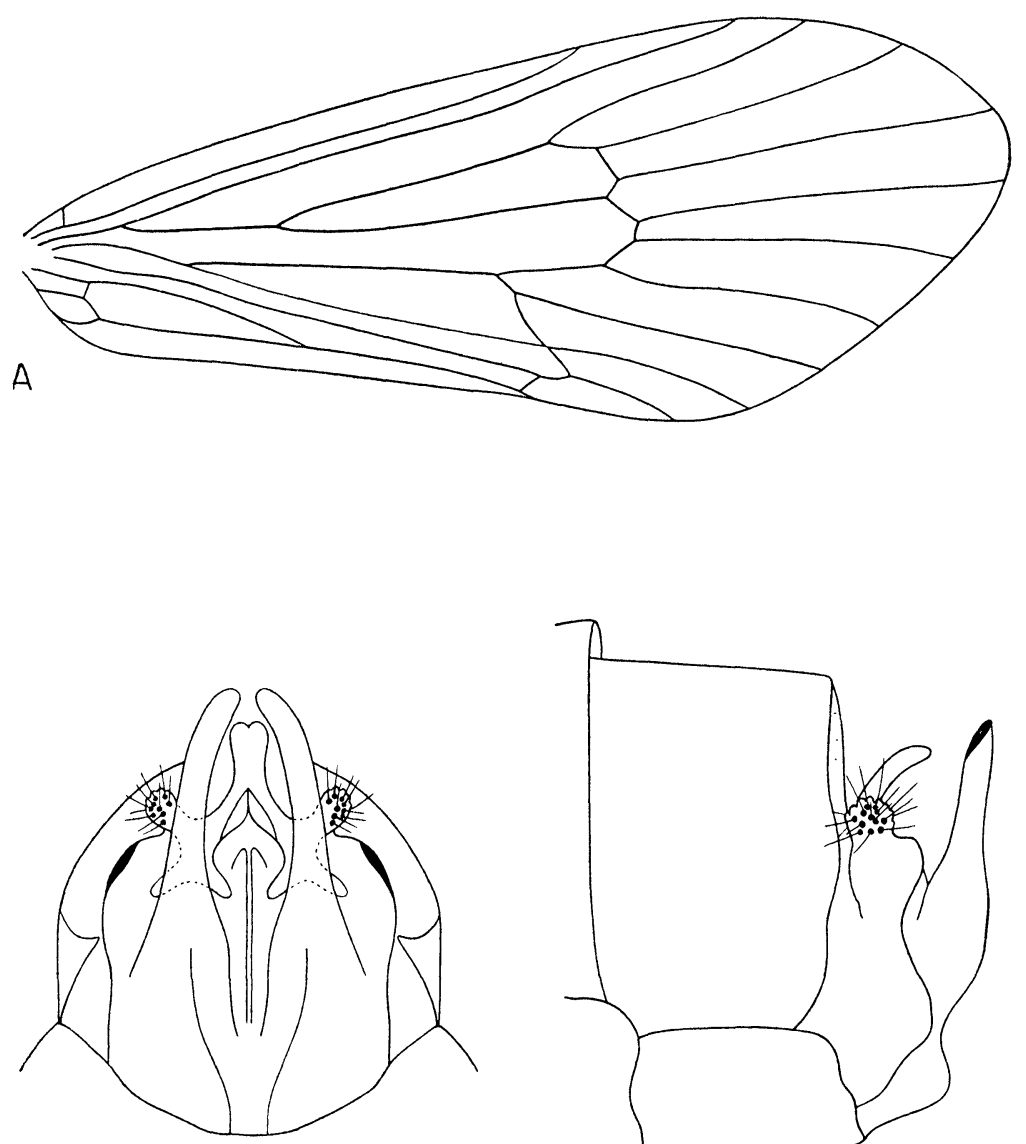

B

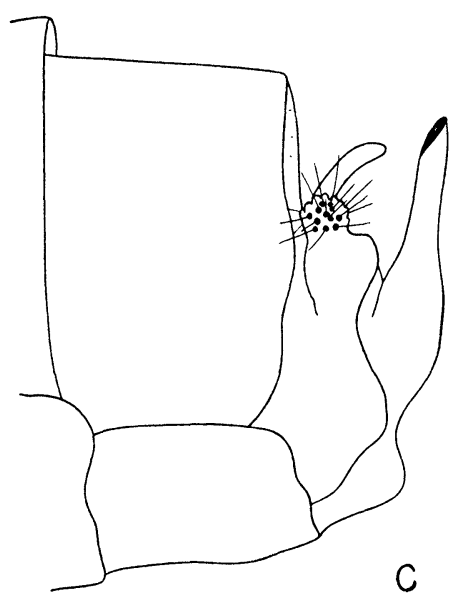

Figure 1. Hydatophylax victor, sp. nov. A, fore wing; B, posterior view. and C, lateral view, of end of abdomen of male. 

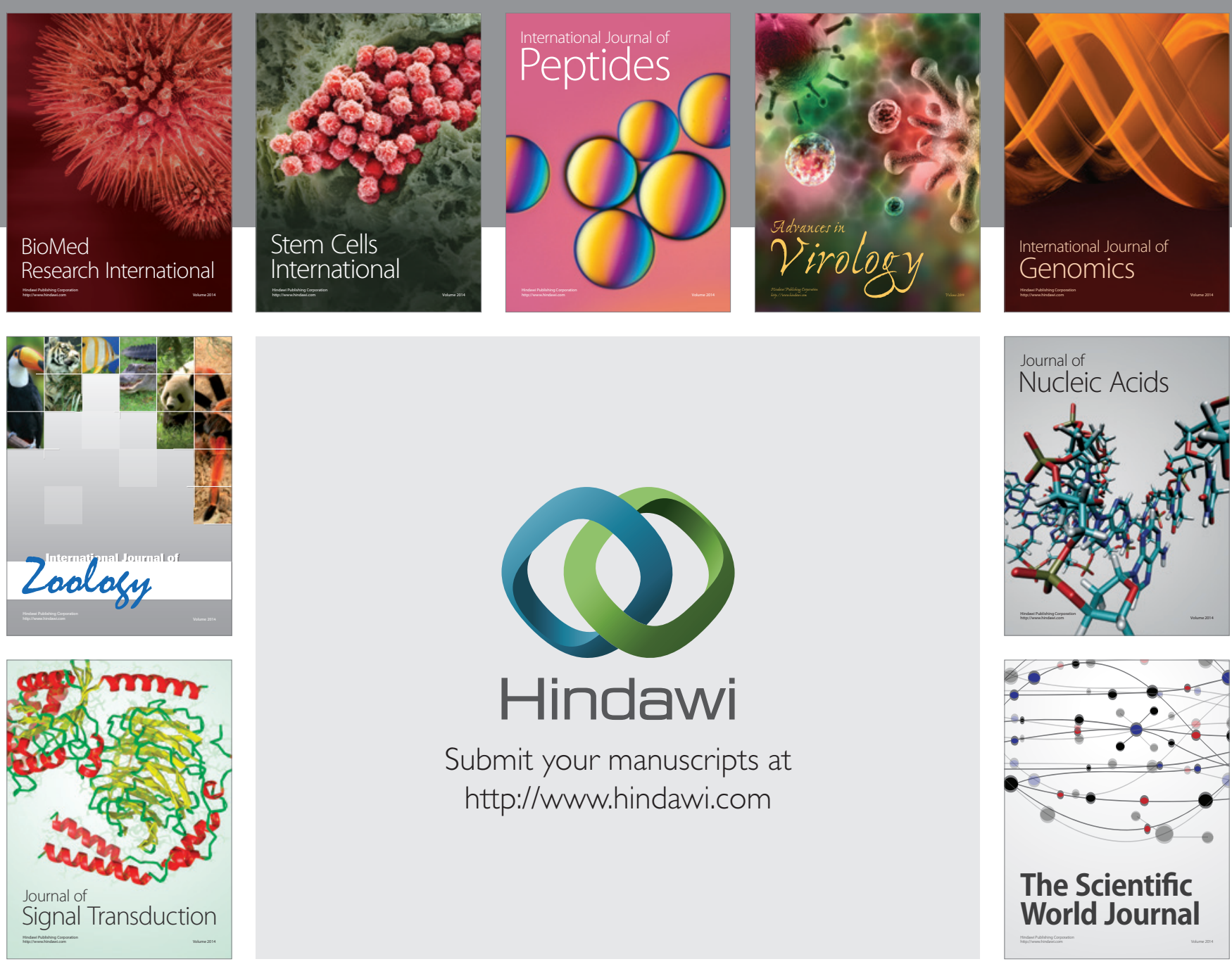

Submit your manuscripts at

http://www.hindawi.com
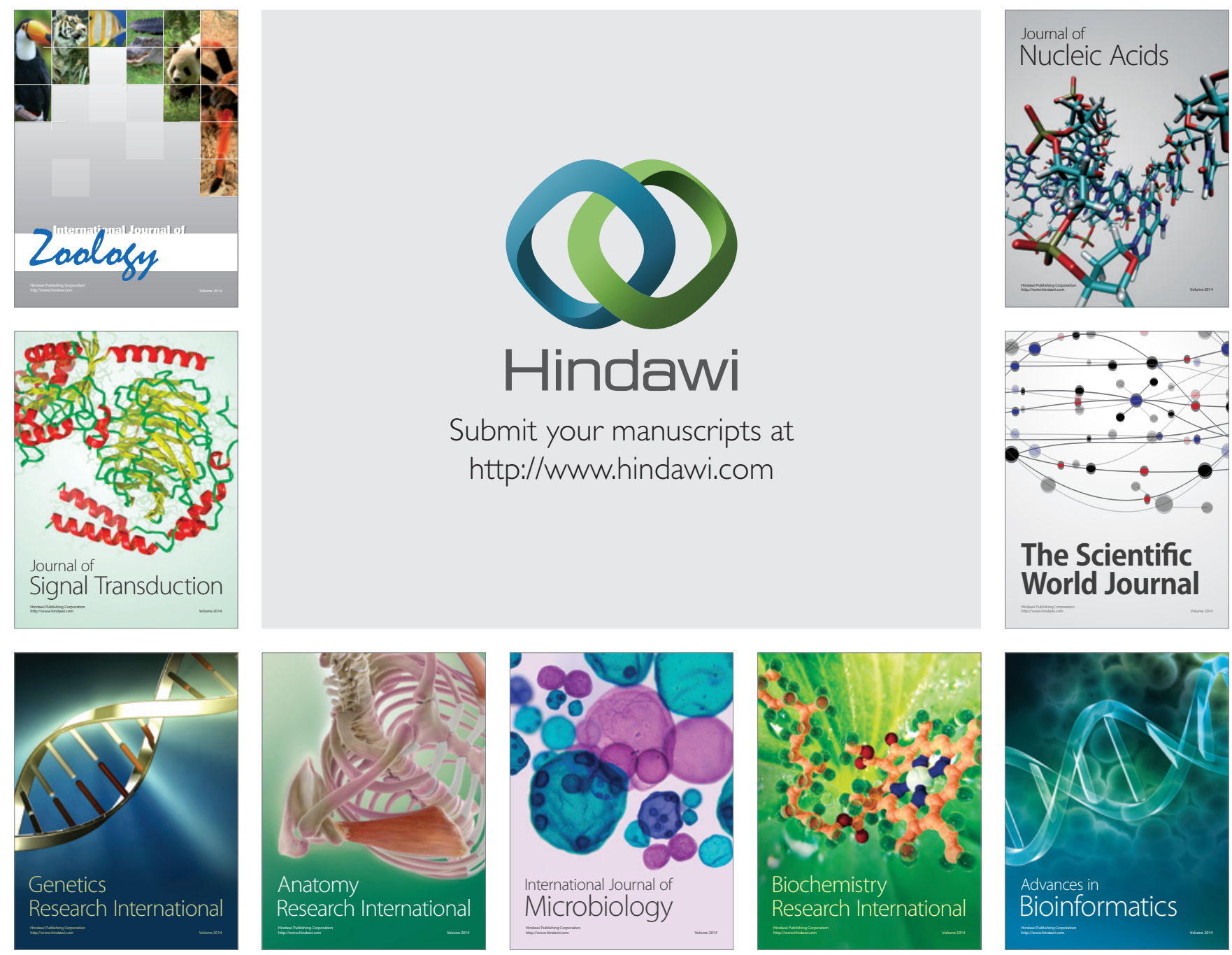

The Scientific World Journal
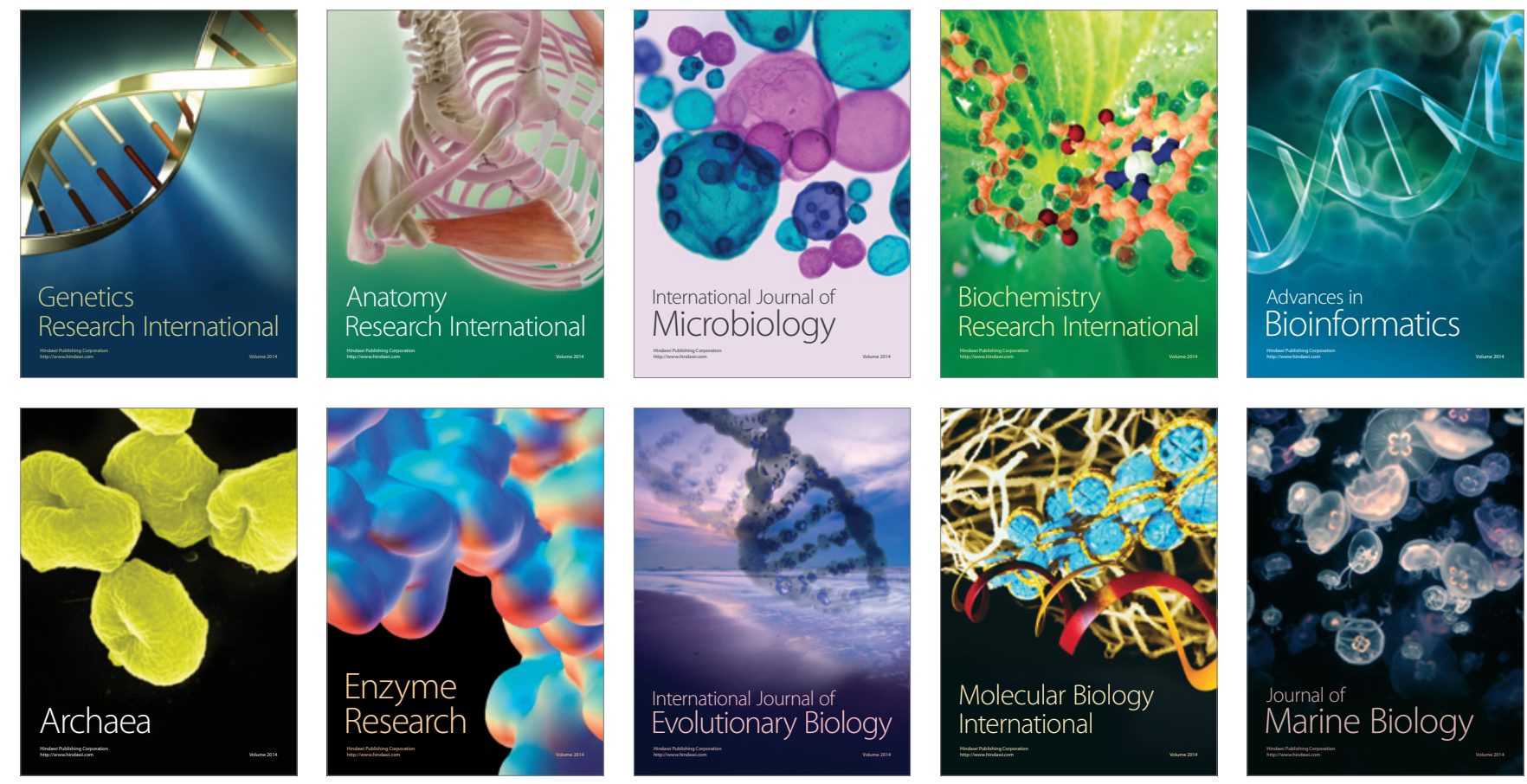